Kodifikasia : Jurnal Penelitian Islam, Vol 14, No. 02 (2020), 263-281

DOI : 10.21154/kodifikasia.v14i2.2197

ISSN : 1907-6371 (Cetak)

ISSN : 2527-9254 (Online)

\title{
HUKUM KELUARGA ISLAM RAMAH GENDER: ELABORASI HUKUM KELUARGA ISLAM DENGAN KONSEP MUBADALAH
}

\author{
Anis Hidayatul Imtihanah*
}

\begin{abstract}
Abstrak
Artikel ini mengelaborasi hukum keluarga Islam dengan prinsip mubadalah yang bertujuan untuk meminimalisir praktik dominasi, subordinasi dan bahkan kekerasan dalam keluarga. Sehingga sangat perlu mengangkat topik tentang relasi gender suami istri dalam keluarga untuk "membuka mata" akan pentingnya relasi yang sadar gender. Melalui kajian ini, diharapkan mampu mempertahankan akar hukum keluarga Islam yang ramah gender sehingga tidak akan ada lagi praktik dominasi dan subordinasi dalam kehidupan rumah tangga. Penelitian ini menggunakan metode kepustakaan (library research) dengan mengkaji berbagai macam sumber literatur yang berkaitan dengan topik relasi gender dalam keluarga sekaligus memadukannya dengan pendekatan feminis. Berdasarkan hasil penulusuran dari berbagai sumber referensi dijelaskan bahwa pola relasi suami istri yang baik itu adalah berdasar pada prinsip Al-Mu'asyarah bi Al-Ma'ruf. Hal tersebut akan terwujud jika kedua belah pihak yaitu suami istri saling memahami sekaligus menjalankan hak-hak dan kewajibannya secara resiprokal dan proposional, sehingga akan tercipta keselarasan. Tidak ada dominasi antara suami istri karena keduanya adalah saling melengkapi. Selain itu, keberadaan prinsip mubadalah dalam Hukum Keluarga Islam merupakan sebuah keniscayaan untuk mewujudkan tatanan hukum yang ramah gender dalam keluarga Islam.
\end{abstract}

Kata Kunci: Relasi gender; Suami istri; Hukum keluarga Islam.

\footnotetext{
* Institut Agama Islam Negeri Ponorogo, email: anishid@iainponorogo.ac.id
} 


\begin{abstract}
This study elaborates on Islamic family law with the principle of mubadalah which aims to minimize the practice of domination, subordination and even violence in the family. Moreover, the discussion also reveals the importance of gender-awareness relations in the family life. Through this study, it is expected to be able to maintain the root of Islamic family law in the gender-friendly relation point of view. So, there will be no more practices of domination and subordination in the domestic life. This research uses the library research method by examining various sources of literature related to the topic of gender relations in the family and also involves the feminist approach. The results show that the pattern of an ideal relationship between husband and wife is based on the principle of Al-Mu'asyarah bi Al-Ma'ruf. It can be realized if the husband and wife can understand each other and at the same time carry out their rights and obligations proportionally and reciprocally, thereby the harmony can be realized. There is no domination between husband and wife because both are complementary. In addition, the existence of the principle of mubadalah in Islamic Family Law is a necessity to realize and optimize a gender-friendly legal order in the Islamic family.
\end{abstract}

Keywords: Gender relations; Husband and wife; Islamic family law.

\title{
PENDAHULUAN
}

Kehidupan dalam sebuah rumah tangga sangat membutuhkan adanya kebersamaan dan sikap saling berbagi antara suami dan istri. Hal tersebut bertujuan agar suami dan istri harus berhubungan dengan bentuk hubungan saling (mutual relation), yang artinya adalah adanya hubungan timbal balik antara suami dan istri. Dengan kata lain antara kedua belah pihak yang berhubungan saling menguntungkan dan tidak ada pihak yang dirugikan. Hubungan antara suami istri tersebut tentunya juga harus berdasar pada cinta, kasih sayang, dan kesetaraan. ${ }^{1}$ Setidaknya terdapat dua unsur pokok yang dapat mewujudkan sebuah keluarga yang penuh ketenangan. Pertama, pola hubungan suami dan istri. Keberhasilan menciptakan relasi yang seimbang antara suami istri, akan menjadi embrio lahirnya nuansa

${ }^{1}$ C.A. Soorma and Al- Hajj Khwaja Kamaluddin, The Status of Woman in World Religions and Civilizations and Status of Woman in Islam (Bombay: Dar-ul-Isha'at-Kutub-eIslami, 1996), 85. 
bahagia dalam keluarga. Kedua, pola hubungan timbal balik (resiprokal) antara orang tua dan anak- anak. ${ }^{2}$

Eksistensi suatu relasi dan interaksi yang baik antara suami dan istri serta seluruh anggota keluarga lainnya merupakan sarana untuk mewujudkan kebahagiaan dan ketenangan dalam rumah tangga. Selain itu dibutuhkan pula pemenuhan hak dan kewajiban antara pasangan suami dan istri dengan cara yang seimbang. Hal tersebut bertujuan untuk mengidentifikasi posisi suami dan istri dalam kehidupan rumah tangga. Apakah ada kesenjangan yang tercermin ke dalam bentuk subordinasi antara kedua belah pihak suami dan istri, ataukah sebaliknya suami dan istri memiliki posisi yang seimbang. Hal tersebut adalah juga sebagai salah satu upaya dan sarana untuk mewujudkan keluarga sakinah dalam rumah tangga.

Analisis terhadap kajian gender bertujuan untuk mengeksplorasi fenomena ketidaksetaraan dan ketidakadilan yang terjadi antara laki- laki dan perempuan -dalam konteks ini adalah suami istri- yang terefleksikan dalam mindset dan stereotipe adanya pelabelan negatif terhadap salah satu jenis kelamin. Ketidakadilan gender tersebut termanifestasikan dalam beberapa bentuk seperti inferioritas, subordinasi, marjinalisasi, perlakuan diskriminatif, dan kekerasan. ${ }^{3}$

Laki-laki sebagai suami dengan sifat maskulin dalam konstruk budaya ditempatkan pada posisi sebagai kepala rumah tangga. Sementara itu, perempuan sebagai istri ditempatkan pada posisi kedua dalam kehidupan rumah tangga. Hal ini dalam budaya Jawa disebut dengan ungkapan bahwa istri adalah konco wingking suami. Dengan kata lain, kewajiban utama seorang istri adalah mengurus suami dan rumah tangga, kemudian istri yang baik adalah istri yang patuh dan selalu manis kepada suami. ${ }^{4}$ Hak dan kewajiban perempuan yang diatur dalam Islam secara tekstual terkadang tampak sangat mendiskriminasikan perempuan sebagai makhluk Tuhan. Hal ini sangat bertentangan dengan peraturan internasional tentang hak asasi manusia yang menyatakan bahwa laki- laki dan perempuan mempunyai tanggung jawab yang sama baik dalam bidang politik, ekonomi, sosial, budaya, pemerintahan/sipil, dan bidang- bidang lainnya sebagaimana disebutkan dalam The Convention on the Elimination of all Forms of Discrimination Against Women (CEDAW). ${ }^{5}$

\footnotetext{
${ }^{2}$ Nashir Sulaiman Al-Umar, Ada Surga Di Rumahku (Sukoharjo: Insan Kamil, 2007), $5-6$.

${ }^{3}$ Susilaningsih, Dar-Ul-Isha'at-Kutub-e-Islami (Kerjasama UIN SUKA Yogyakarta dengan McGill-IAIN-Indonesia Social Equity Project, 2004), 13.

${ }^{4}$ Khoiruddin Nasution, Islam Tentang Relasi Suami Dan Istri; Hukum Perkawinan (Yogyakarta: ACAdeMIA+TAZZAFA, 2004), 3.

5 Ann Elizabeth Mayer, Islam Tradition and Politics Human Rights (Colorado: Westview Press, 1995), 118.
} 
Sebuah relasi gender menuntut termanifestasikannya kesetaraan, keadilan, persamaan akses (access) dan kesempatan (opportunity) antara lakilaki dan perempuan yaitu bahwa mereka sama- sama memiliki kesempatan untuk mewujudkan hak- hak dan potensinya untuk berkontribusi pada perkembangan politik, hukum, ekonomi, sosial, agama, dan budaya. ${ }^{6}$

Sebagai bahan untuk melakukan positioning dalam artikel ini, penulis mengkaji beberapa kajian literatur yang memiliki tema serumpun. Diantaranya adalah artikel yang berakar dan berangkat dari gagasan Amina Wadud tentang interpretasi gender dan feminisme di dalam Alquran. Wadud berpendapat bahwa perempuan dalam Islam adalah makhluk yang sempurna dan mempunyai peran, tugas dan posisi yang seimbang dengan laki-laki. Akan tetapi kultur budaya Islam selama ini cenderung menganggap bahwa laki-laki dan perempuan adalah berbeda. Sehingga dirasa perlu untuk menginterpretasi teks-teks agama -Islam- tersebut dari sudut pandang gender dan feminisme tentang permasalahan-permasalahan dalam keluarga serta status perempuan dalam rumah tangga. ${ }^{7}$

Selanjutnya artikel yang mengulas tentang relasi gender suami istri dengan fokus tentang pandangan para tokoh perempuan organisasi Aisyiyah yang sepakat bahwa bolehnya istri mencari nafkah dan menjadi (pemimpin) kepala keluarga. Dengan kata lain, hal tersebut menunjukkan keseimbangan relasi antara suami dan istri dalam keluarga. ${ }^{8}$

Adapun fokus bidikan dalam tulisan ini adalah pada eksplorasi relasi gender yang ideal pasangan suami istri dalam kehidupan rumah tangga dalam Islam. Hal tersebut bertujuan untuk mewujudkan tatanan hukum Keluarga Islam yang ramah gender serta mengelaborasikannya dengan prinsip mubadalah.

Penelitian ini menggunakan metode kepustakaan (library research) dengan mengkaji berbagai macam sumber literatur yang berkaitan dengan topik relasi gender dalam keluarga. Dengan memadukan pendekatan feminis sebagai lensa untuk melihat dan menganalisis lebih dalam tentang wujud ketimpangan gender yang terdapat dalam teks agama maupun narasi peraturan perundangan tentang relasi suami istri dalam keluarga. Karena salah satu karakter pendekatan feminis adalah sebagai upaya untuk

${ }^{6}$ Dar-Ul-Isha'at-Kutub-e-Islami, 23.

7 Cahya Edi Setyawan, "Pemikiran Kesetaraan Gender Dan Feminisme Amina Wadud Tentang Eksistensi Wanita Dalam Kajian Hukum Keluarga," Zawiyah: Jurnal Pemikiran Islam 3, no. 1 (2017): 70-91.

8 Ahmad Arif Syarif, "Relasi Gender Suami Istri: Studi Pandangan Tokoh Aisyiyah," Sawwa: Jurnal Studi Gender 13, no. 1 (2018): 85-106. 
mencipatakan sebuah gagasan baru dengan 'mengangkat' perempuan sebagai salah satu wujud kesetaraan antara laki-laki dan perempuan. ${ }^{9}$

Berdasarkan hasil penulusuran dari berbagai sumber referensi dijelaskan bahwa pola relasi suami istri yang baik itu adalah berdasar pada prinsip Al-Mu'asyarah bi Al-Ma'ruf. Hal tersebut akan terwujud jika kedua belah pihak yaitu suami istri saling memahami sekaligus menjalankan hak-hak dan kewajibannya secara resiprokal dan proposional, sehingga dalam pelaksanannya akan tercipta keselarasan serta tidak ada dominasi antara suami istri karena keduanya adalah saling melengkapi. Selain itu, keberadaan prinsip mubadalah dalam Hukum Keluarga Islam merupakan sebuah keniscayaan untuk mewujudkan tatanan hukum yang ramah gender dalam keluarga Islam.

\section{PEMBAHASAN}

Mu'asyarah bil al- ma'ruf atau bergaul secara baik merupakan prinsip relasi suami istri dalam Islam. Praktiknya adalah dengan mengimplementasikan hubungan resiprokal antara suami istri dalam kehidupan berumah tangga. ${ }^{10}$ Suami istri diharuskan bisa saling memahami dan melengkapi satu sama lain. Pelaksanaan hak dan kewajiban harus dilandasi oleh beberapa prinsip, antara lain kesamaan, keseimbangan, dan keadilan antara keduanya. Yaitu implementasi hak dan kewajiban yang bersifat material (lahir) maupun yang non material (batin) ${ }^{11}$ Dengan demikian relasi antara pasangan suami istri dilaksanakan atas dasar kemitraan dan kesejajaran tanpa harus ada paksaan atau tindakan kekerasan di antara suami istri.

Mu'asyarah bil al- ma'ruf merupakan prinsip dasar relasi suami istri, prinsip tersebut tidak hanya berlaku bagi pasangan suami-istri saja, namun juga berlaku untuk anggota keluarga yang lain. Sehingga terdapat hubungan simbiosis mutualisme. Hal tersebut sebagai salah satu cara dalam pembentukan keluarga sakinah, karena tidak akan ada superioritas dan inferioritas dalam suatu keluarga.

Menurut Islam konsep hubungan suami dan istri yang ideal adalah konsep kemitrasejajaran atau hubungan yang setara dan seimbang serta komplementer. ${ }^{12}$ "... Istri-istri kamu, mereka adalah pakaian bagimu dan kamu pun adalah pakaian bagi mereka." (Q.S. Al- Baqarah: 187). Ayat tersebut

\footnotetext{
${ }^{9}$ Peter Connolly, Approaches to the Study of Religion (Yogyakarta: IRCiSoD, 2016), 77.

${ }^{10}$ Marhumah, Membina Keluarga Mawaddah Wa Rahmah Dalam Bingkai Sunnah Nabi (Yogyakarta: PSW IAIN Sunan Kalijaga, 2003), 312.

${ }^{11}$ Husein Muhammad, Figh Perempuan: Refleksi Kiai Atas Wacana Agama Dan Gender (Yogyakarta: LKiS, 2001), 108.

${ }^{12}$ Ratna Batara Munti, Perempuan Sebagai Kepala Rumah Tangga (Jakarta: Lembaga Kajian Agama dan Jender, 1999), 56.
} 
menjelaskan bahwa istri itu adalah pakaian bagi suaminya dan sebaliknya suami adalah pakaian bagi sang istri. Jadi, keduanya saling melengkapi. Segala bentuk kegiatan dalam keluarga dilakukan secara "mutually" artinya ada proses sharing atau saling berbagi peran antara pasangan suami- istri serta anggota keluarga yang lain. ${ }^{13}$ Hal tersebut sebagai salah satu upaya pembentukan keluarga sakinah.

Adapun konsep peran (role concept) yang diprakarsai oleh F. Ivan Nye, menyatakan bahwa terdapat dua aliran dalam sosiologi mengenai konsep peran dalam keluarga, yaitu normatif dan interaksionis. Peran normatif memberikan gambaran bahwa sebuah keluarga dan para anggotanya mempunyai peran yang telah ditentukan dan bersifat rigid/tetap. Sedangkan peran interaksionis merupakan suatu konsepsi peran sebagai keteraturan tingkah laku yang dihasilkan dari wujud interaksi sosial, dengan kata lain bahwa peran itu muncul akibat dari adanya interaksi sosial. ${ }^{14}$

Selain itu juga diperlukan suatu perspektif gender yang digunakan dalam mengungkapkan dan menunjukkan fenomena gender dalam suatu masyarakat serta berbagai persoalan sosial-budaya yang ditimbulkannya. Perspektif ini dapat menumbuhkan kepekaan kita terhadap fenomena ketidakadilan gender menjadi lebih kuat. Selain itu juga memberikan perhatian pada pola-pola interaksi, relasi, dan pemisahan peran antara lakilaki dan perempuan, dan juga berbagai macam implikasinya.

\section{Fungsi dan Tujuan Keluarga}

Keluarga terdiri dari dua suku kata, yaitu kula yang berarti abdi, hamba, yang mengabdi untuk kepentingan bersama; dan warga yang berarti anggota, yang berhak ikut berbicara dan bertindak. Dengan demikian keluarga merupakan perpaduan kata- kata yang arti keseluruhannya yaitu mengabdi, bertindak, dan bertanggung jawab kepada kepentingan umum. ${ }^{15}$ Dalam definisi lain disebutkan, bahwa keluarga merupakan institusi yang terkecil dalam suatu masyarakat yang memiliki fungsi sebagai sarana untuk mewujudkan kehidupan yang aman, tenteram, damai, dan sejahtera dalam nuansa yang penuh cinta dan kasih sayang di antara semua anggotanya. ${ }^{16}$

Keluarga dalam Islam didefinisikan sebagai sebuah unit yang terdiri dari laki- laki (suami) dan perempuan (istri) yang hidup bersama dan saling 13.

${ }^{13}$ F. Ivan Nye, Role Structure and Analysis of the Family (USA: Sage Publication, 1976),

${ }^{14}$ Nye, $4-5$.

${ }^{15}$ Aisyah Dachlan, Membina Rumah Tangga Bahagia Dan Peranan Agama Dalam Rumah Tangga (Jakarta: Jamunu, 1969), 32.

${ }^{16}$ Sri Mulyati, Relasi Suami Istri Dalam Islam (Jakarta: PSW UIN Syarif Hidayatullah, 2004), 39.

Kodifikasia: Jurnal Penelitian Islam, Volume, 14 No. 2 Tahun 2020 
berbagai dengan berdasar pada hukum- hukum dan aturan- aturan dalam syari'ah. Kehormatan suami adalah juga merupakan kehormatan bagi istri, dan begitu pula sebaliknya, dengan demikian keduanya harus saling menjaga kehormatan satu sama lain. Mereka juga saling berbagi suka maupun duka. ${ }^{17}$

Keluarga merupakan suatu basis dan cikal bakal dalam hidup manusia. Pembinaan dalam keluarga hal yang penting, karena akan menjadikan keluarga yang sakinah di mana menjadi salah satu pilar penopang masyarakat Islam. Sehingga hal tersebut menjadi perhatian dalam Islam. Daya tarik ini dapat mempersatukan mereka dalam jalinan yang bermakna, yaitu sistem keluarga. Keluarga adalah suatu tempat pengasuhan secara alami dapat memelihara anak yang sedang tumbuh, mampu mengembangkan fisik, daya nalar dan jiwa mereka. ${ }^{18}$ Selain itu, keluarga juga merupakan suatu kelompok sosial yang di dalamnya terdapat hubungan seksual antara orangorang yang sudah dewasa, yang akan menghasilkan keturunan (anak-anak) secara legal. Kelompok sosial ini yang memiliki tanggung jawab terhadap masyarakat mengenai pengasuhan dan pendidikan anak-anak. ${ }^{19}$

Soerjono Soekanto juga menjelaskan bahwa pembicaraan tentang keluarga yang dibatasi pada keluarga batih (keluarga inti/nuclear family) yaitu suami/ayah, istri/ibu dan anak-anak yang belum menikah. Keluarga batih merupakan unit pergaulan hidup terkecil yang terdapat dalam masyarakat. Selain itu, juga terdapat unit-unit pergaulan hidup lainnya, seperti keluarga luas (extended family) dan komunitas (community). ${ }^{20}$

Keluarga batih memiliki peranan-peranan tertentu, sebagai unit pergaulan hidup terkecil dalam masyarakat. Peranan-peranan tersebut diantaranya:

a. Sebagai pelindung bagi pribadi-pribadi yang menjadi anggota, sehingga mendapat ketenteraman dan ketertiban.

b. Keluarga batih merupakan unit sosial-ekonomis, sehingga secara materiil dapat memenuhi kebutuhan anggotanya.

c. Dapat menumbuhkan dasar-dasar serta kaidah-kaidah dalam pergaulan hidup.

d. Sebagai wadah di mana manusia mengalami proses sosialisasi awal, yaitu proses di mana manusia mempelajari, mematuhi kaidah-kaidah dan nilai-nilai dalam masyarakat. ${ }^{21}$

${ }^{17}$ Abdur Rahman I Doi, Women in Shari'ah (Islamic Law) (Malaysia: A. S. Noordeen, 1992), 11. 160.

${ }^{18}$ Miftahul Huda, Filsafat Hukum Islam (Ponorogo: STAIN PO Press, 2006),

${ }^{19}$ Nabil Muhammad Taufik As- Samaluthi, Pengaruh Agama Terhadap Struktur Keluarga (Surabaya: PT Bina Ilmu, 1987), 128.

${ }^{20}$ Soerjono Soekanto, Sosiologi Keluarga (Jakarta: PT RINEKA CIPTA, 2004), 22.

${ }^{21}$ Soekanto, 23. 
Berdasarkan pemaparan tentang peranan keluarga tersebut di atas, maka tampak jelas bahwa peranan keluarga itu sangat pokok dan penting khususnya bagi tumbuh-kembang kepribadian seseorang. Rusyidhi menjelaskan bahwa keluarga merupakan suatu institusi yang minimal memiliki beberapa fungsi diantaranya:

a. Fungsi religius, yaitu keluarga dapat memberikan pengalaman keagamaan kepada anggotanya.

b. Fungsi afektif, yaitu keluarga dapat memberikan kasih sayang dan melahirkan keturunan.

c. Fungsi sosial, yaitu keluarga dapat memberikan prestise dan status kepada tiap anggotanya.

d. Fungsi edukatif, yaitu keluarga dapat memberikan pendidikan kepada anak-anaknya.

e. Fungsi protektif, yaitu keluarga dapat melindungi anggotanya dari berbagai ancaman baik fisik, ekonomis, dan psiko-sosial.

f. Fungsi rekreatif, yaitu keluarga merupakan wadah rekreasi (hiburan) bagi anggotanya. 22

Fungsi keluarga di atas dapat terealisasi dan berjalan secara optimal jika semua anggota keluarga bahu-membahu dan selaras dalam melaksanakan tanggung jawab serta hak dan kewajiban tiap anggotanya sehingga terbangun suatu sinergitas dan keseimbangan dalam keluarga. ${ }^{23}$ Seperti yang telah dibahas sebelumnya, bahwa keluarga merupakan "wadah" yang darinya manusia dengan kepribadian yang baik berasal. Keberhasilan dan kekalahan suatu masyarakat sangat ditentukan oleh moral, etika dan akhlak yang melandasi sebuah institusi keluarga. ${ }^{24}$

Dalam hal ini perlu ditekankan bahwa komitmen untuk berumah tangga tidak hanya didasari oleh kebutuhan fitrah lawan jenis saja, akan tetapi berumah tangga merupakan suatu bagian yang tidak terpisahkan dari ibadah dan dakwah. Sebagai ibadah, berumah tangga yaitu sarana untuk meningkatkan dan menyempurnakan amaliah ibadah kepada Allah, sedangkan sebagai dakwah, berumah tangga yaitu sarana untuk saling mengingatkan dalam kebaikan, dan juga berkompetisi dalam hal memberi teladan yang baik dalam hal apapun.

${ }^{22}$ Nur Chozin Ar Rusyidhi, Rahasia Keluarga Sakinah (Yogyakarta: Sabda Media, 2008), 16.

${ }^{23}$ Ar Rusyidhi, 16.

${ }^{24}$ Ayatullah Husain Mazhahiri, Membangun Surga Dalam Rumah Tangga (Bogor: Yayasan IPABI, 1993), 8. 


\section{Kemitrasejajaran antara Suami dan Istri}

Menurut Islam konsep relasi antara suami dan istri yang ideal adalah konsep kemitrasejajaran atau hubungan yang setara dan seimbang. Seorang istri adalah ibarat pakaian bagi suaminya, dan demikian sebaliknya bahwa suami adalah laksana pakaian bagi istrinya. Dengan demikian, suami dan istri adalah komplementer, keduanya saling melengkapi. ${ }^{25}$

Dalam kehidupan sehari-hari prinsip kesetaraan atau kemitrasejajaran dalam hubungan antara suami istri ini tidak begitu saja mudah diterapkan. Karena pasti akan ada beragam kendala untuk merealisasikan nilai yang ideal dan mulia tadi. Setiap manusia tentunya mempunyai kelemahan dan keterbatasan satu sama lain. Kemampuan antara satu manusia satu dengan yang lain memiliki tingkatan yang berbeda. Oleh karena itu, wajar jika pada satu masa kaum laki-laki menjadi unggul dan berhak menjadi seorang pemimpin, karena pada masa itu laki-laki mempunyai suatu kelebihan kekayaan, sedangkan kaum perempuan pada waktu itu pada kondisi yang sebaliknya.

Dengan demikian, pada dasarnya kedudukan laki-laki ataupun perempuan adalah seimbang (setara). Laki- laki (suami) dan perempuan (istri) memiliki hak yang sama, tidak ada yang lebih tinggi atau pun lebih rendah antara satu dengan yang lainnya. Bahkan dalam kondisi tertentu secara perempuan juga bisa menjadi kepala keluarga karena kelebihan yang dimilikinya. ${ }^{26}$ Dengan menggarisbawahi bahwa seorang perempuan dibolehkan melakukan pekerjaan di luar pekerjaan rumah tangga (public sphere), akan tetapi tetap tidak melupakan tugas utamanya sebagai istri (domestic sphere). ${ }^{27}$

\section{Relasi Gender Suami Istri dalam Keluarga}

Dalam Kamus Besar Bahasa Indonesia disebutkan bahwa kata relasi memiliki makna hubungan, perhubungan, pertalian dengan orang lain. ${ }^{28}$ Sedangkan relasi gender adalah hubungan kemanusiaan (sosial) yang didasarkan pada pertimbangan aspek kesadaran gender. ${ }^{29}$ Menurut Nasaruddin Umar, relasi gender adalah sebuah konsep dan realitas pembagian kerja seksual antara laki-laki dan perempuan yang tidak didasarkan pada pemahaman

\footnotetext{
${ }^{25}$ Munti, Perempuan Sebagai Kepala Rumah Tangga, 57.

${ }^{26}$ Munti, 59.

${ }^{27}$ Istiadah Istiadah, Pembagian Kerja Rumah Tangga Dalam Islam (Jakarta: Lembaga Kajian Agama dan Jender, 1999), 23.

${ }^{28}$ Departemen Pendidikan Nasional, Kamus Besar Bahasa Indonesia (Jakarta: Balai Pustaka, 2001), 943.

${ }^{29}$ Yuniyanti Chuzaifah Dkk, Realita Dan Cita Kesetaraan Gender Di UIN Jakarta: Baseline Dan Analisa Institusional Pengarusutamaan Gender Pada UIN Syarif Hidayatullah Jakarta Tahun 1999- 2003 (Jakarta: Mc Gill IAIN- Indonesia Social Equity Project, 2004).
} 
yang bersifat normatif serta kategori biologis, melainkan pada kualitas, kemampuan, dan peran berdasarkan konvensi sosial. Oleh karena itu, konsep dan manifestasi dari relasi gender menjadi dinamis dan memiliki fleksibelitas yang mempertimbangkan variabel psiko-sosial yang berkembang. Relasi tersebut dimaksudkan sebagai hubungan baik dan harmonis antara satu anggota dengan anggota keluarga yang lain. ${ }^{30}$ Relasi gender dalam kajian ini dibatasi pada relasi gender antara suami- istri dalam rumah tangga.

Asma Barlas mengungkapkan bahwa dalam kehidupan keluarga, Kitab Suci Al- Qur'an secara penuh mendukung kesetaraan antara laki-laki dan perempuan. Meskipun pada dasarnya terdapat perbedaan biologis antara laki- laki dan perempuan, namun perbedaan jasad yang bersifat fisik tidak menjadikan mereka berbeda dalam suatu etika dan moral. Selain itu, lakilaki dan perempuan juga memiliki kesetaraan, dan persamaan yaitu pada tingkat ontologism. Pada tingkat ini laki- laki dan perempuan diciptakan dari nafs (single self). Selain itu, persamaan antara laki- laki dan perempuan yaitu memiliki kapasitas yang sama sebagai agen moral (moral agency). Singkatnya, mereka sama-sama mempunyai tugas kemanusiaan yang tidak berbeda. ${ }^{31}$

Keselarasan dan keseimbangan antara suami dan istri tersebut meliputi beberapa hal, diantaranya yaitu:

a. Hubungan seksual, di mana hubungan seksual sebagai bagian dari kehidupan berkeluarga dipandang sebagai kebutuhan dua belah pihak, dengan berusaha realistis menerima pasangan hidup kita apa adanya dan berusaha semaksimal mungkin berbuat yang terbaik bagi pasangan kita.

b. Pendidikan keluarga, yaitu pendidikan anak dalam keluarga dipandang sebagai bagian tanggung jawab bersama kedua orang tua dengan memberi teladan yang baik dan bersikap adil terhadap semua anak.

c. Aktualisasi diri, yaitu suami dan istri membutuhkan aktualisasi diri sesuai dengan kebutuhannya, baik berupa pendidikan yang lebih tinggi, aktivitas sosial di masyarakat ataupun bekerja.

d. Pengaturan keuangan dalam keluarga, harus didasarkan pada komunikasi yang aktif dan kesepakatan bersama suami istri. ${ }^{32}$

Islam telah mengajarkan bahwa istri adalah partner/mitra sejajar bagi suaminya baik sebagai sahabat maupun sebagai kekasihnya. Sedangkan partner sendiri diartikan sebagai hubungan antara dua orang atau lebih yang

${ }^{30}$ Dachlan, Membina Rumah Tangga Bahagia Dan Peranan Agama Dalam Rumah Tangga, 32.

${ }^{31}$ Asma Barlas, Cara Qur'an Membebaskan Perempuan/Believing Woman in Islam (Jakarta: PT. Serambi Ilmu Pustaka, 2003), 16-17.

${ }^{32}$ Nurun Najwah, Relasi Ideal Suami Istri (Yogyakarta: PSW IAIN Sunan Kalijaga, 2002), 45-61.

Kodifikasia: Jurnal Penelitian Islam, Volume, 14 No. 2 Tahun 2020 
berbeda tetapi saling membutuhkan dalam mencapai suatu tujuan tertentu. Sehingga, suami dan istri merupakan dua orang yang saling membutuhkan untuk mencapai tujuan keluarga sakinah dan bahagia lahir dan batin. Sehingga tidak ada yang lebih istimewa/superior di antara mereka dari segi status tersebut. ${ }^{33}$

Pemahaman tentang hubungan partnership antara suami istri dalam Islam seperti yang dijelaskan di atas merujuk pada surat $\mathrm{Al}$ - Baqarah ayat 187:

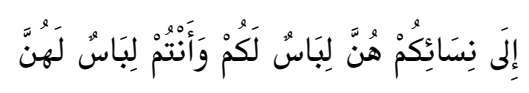

Artinya: “...Isteri-isteri kamu; mereka adalah pakaian bagimu, dan kamu pun adalah pakaian bagi mereka." ${ }^{34}$ (Q.S. Al- Baqarah: 187)

Kata libasun dalam bahasa Arab berarti pakaian. Pakaian secara zhahir berarti sesuatu yang menutupi tubuh dan melindunginya. Suami dan istri digambarkan Allah sebagai pakaian berarti keduanya saling menutupi kekurangan masing- masing. Kalau pakaian menutupi tubuh dari berbagai gangguan seperti cuaca misalnya seperti dingin dan panas, maka suami yang merupakan pakaian bagi istri juga berfungsi untuk menutupi aib dan kekurangan istrinya, dan begitu pula sebaliknya kekurangan suami dapat ditutupi pula oleh istrinya. Kalau pakaian dapat melindungi pemakainya maka suami sebagai pakaian istrinya dapat melindungi istrinya dari segala sesuatu yang akan membahayakan istrinya dan begitu pula sebaliknya istrinya juga menjadi pelindung bagi semuanya. ${ }^{35}$

Dalam mengarungi bahtera rumah tangga pasangan suami istri tentunya akan menghadapi berbagai hambatan dan rintangan serta akan ada beragam permasalahan kehidupan. Hal tersebut karena memang lakilaki dan perempuan memiliki karakter yang berbeda sekaligus berasal dari latar budaya yang berbeda. Sehingga sangat dibutukan relasi dan komunikasi yang baik di antara pasangan suami istri untuk mewujudkan rumah tangga yang harmonis dan selaras.

Mu'asyarah bil al- ma'ruf atau bergaul secara baik merupakan prinsip relasi suami istri dalam Islam. Praktiknya adalah dengan mengimplementasikan hubungan resiprokal atau timbal balik antara suami istri. ${ }^{36}$ Suami istri diharuskan bisa saling memahami dan melengkapi satu sama lain. Pelaksanaan hak dan kewajiban harus dilandasi oleh beberapa prinsip, antara lain kesamaan, keseimbangan, dan keadilan antara

${ }^{33}$ Erwati Aziz, Relasi Jender Dalam Islam (Kartasura: PSW STAIN Surakarta Press, 2002), 31.

${ }^{34}$ Departemen Agama RI, Mushaf Al-Qur'an Terjemah, t,t., 30.

${ }^{35}$ Aziz, Relasi Jender Dalam Islam, 33.

${ }^{36}$ Membina Keluarga Mawaddah Wa Rahmah Dalam Bingkai Sunnah Nabi, 312. 
keduanya. Dengan demikian relasi antara suami istri dilaksanakan atas dasar kemitraan dan kesejajaran tanpa harus ada paksaan atau tindakan kekerasan di antara keduanya.

Al-ma'ruf merupakan cerminan hati yang penuh dengan kasih sekaligus unsur pokok yang harus ada dalam relasi suami istri. Karena unsur ini berkaitan erat dengan ucapan, perbuatan dan hati. Di antaranya yaitu:

a. Perkataan yang baik

b. Perbuatan yang baik

c. Hati yang penuh kasih. ${ }^{37}$

Islam memerintahkan pasangan suami istri agar senantiasa bergaul dengan cara yang ma'ruf dalam kehidupan rumah tangga. Karena relasi yang baik (al-mu'asyarah bil ma'ruf) merupakan prinsip dan pedoman dalam mengarungi bahtera rumah tangga dan sekaligus melaksanakan hak dan kewajiban antara suami istri. ${ }^{38}$

Prinsip yang diperlukan untuk merealisasikan relasi yang baik antara suami istri dalam sebuah keluarga, diantaranya:

a. Sikap Saling Memahami

Sikap saling memahami pada saat-saat tertentu pasangan suami istri dapat kembali merujuk dan selalu mengingat kepadanya, sehingga kebahagiaan hidup rumah tangga akan tetap harmonis.

b. Sikap Saling Mengenal

Saling mengenal merupakan suatu dasar untuk dapat saling bertukarpikiran dan saling memahami dalam suatu pasangan suami istri.

c. Tanggung Jawab dan Kerja Sama

Sikap tanggung jawab dan kerja sama dalam memberikan bantuan akan mempermudah pasangan suami istri dalam melakukan tugasnya tanpa harus ada tumpang tindih dalam pelaksanaannya.

d. Kesetiaan dan Keluhuran Cinta

Kesetiaan dan keluhuran cinta terwujud dari sebuah perasaan cinta yang sejati pada pasangan suami istri dan sikap saling pengertian antara keduanya akan terwujud dengan baik. ${ }^{39}$

Manusia dalam hidupnya senantiasa memerlukan ketenangan dan ketenteraman untuk mencapai kebahagiaan. Keluarga yang merupakan unsur kecil dari suatu masyarakat sehingga menjadi faktor terpenting dalam penentuan ketenangan dan ketenteraman masyarakat. Ketenangan dan

${ }^{37}$ Akram Ridha, Menghadirkan Kembali Kehangatan Dalam Rumah Tangga Kita (Surakarta: Ziyad Visi Media, 2007), 41.

${ }^{38}$ Ridha, 9.

${ }^{39}$ Fathi Muhammad Ath- Thahir, Beginilah Seharusnya Suami Istri Saling Mencintai (Bandung: Irsyad Baitus Salam, 2006), 227.

Kodifikasia: Jurnal Penelitian Islam, Volume, 14 No. 2 Tahun 2020 
ketenteraman keluarga itu dapat terwujud dari keberhasilan pembinaan hubungan yang harmonis antara suami istri. Perwujudan keluarga sakinah itu, dapat terwujud dengan adanya kesadaran anggota keluarga dalam menggunakan hak dan pemenuhan kewajiban.

Selain berdasar pada prinsip al-miasyarah bil ma'ruf sebagai upaya untuk mewujudkan keluarga yang berkualitas, ada hal lain yang bisa diterapkan yaitu melalui kebiasaan saling memberi nasehat. Membiasakan diri untuk saling menasehati, maka diharapkan sebuah keluarga akan selalu terjaga dari perbuatan maksiat dan munkar serta akan terjalin relasi yang baik dan penuh rahmah. ${ }^{40}$

Berumah tangga bagi seorang muslim tidak hanya didasari oleh sebuah kebutuhan fitrah berpasangan lawan jenis saja tetapi, berumah tangga merupakan bagian yang tidak dapat terpisahkan dari ibadah dan dakwah. Sebagai ibadah, berumah tangga yaitu sarana untuk meningkatkan dan menyempurnakan amaliah ibadah kepada Allah, sedangkan sebagai dakwah, berumah tangga yaitu sarana untuk saling mengingatkan dalam kebaikan, dan juga berkompetisi dalam hal memberi teladan yang baik dalam hal memberikan contoh terbaik. ${ }^{41}$ Sehingga dakwah tidak hanya dalam konteks suami, istri, dan anak tetapi, bagaimana keluarga dibentuk dan dapat menjadi teladan bagi keluarga lainnya dalam suatu masyarakat.

Setiap pasangan suamiistri tentunya memilikikekurangandan kelebihan. Kekurangan istri atau suami adalah sarana dakwah bagi pasangan masingmasing untuk saling menasehati, melengkapi dan menutupi kekurangan tersebut. Berkaitan dengan hal tersebut, ajaran Islam menganalogikan bahwa hubungan suami istri adalah layaknya seperti sebuah pakaian yang fungsi utamanya adalah sebagai penutup. Dengan kata lain, istri adalah pakaian bagi suami dan sebaliknya suami adalah pakaian bagi istri. Sehingga pasangan suami istri harus berusaha dan bisa saling menutupi kekurangan, menjaga dan menasehati. ${ }^{42}$

Selain itu, perkawinan merupakan pertalian yang kokoh (mitsaqan ghalidzan) sekaligus fondasi bagi terbangunnya kehidupan masyarakat yang baik. Berdasarkan hal tersebut Islam menganjurkan agar pasangan suami dan istri berperilaku yang baik terhadap pasangan masing- masing. Dengan adanya sikap saling pengertian, saling menghargai dan menghormati serta

${ }^{40}$ Mulyana, "Kualitas Keluarga", Dalam Imam Bahroni (Ed.), Dimensi Sosial Islam (Ponorogo: Perpustakaan ISID Kampus Al- Azhar, 2006), 30.

${ }^{41}$ Mulyana, 66.

${ }^{42}$ Mulyana, 67. 
saling mengasihi antara kedua belah pihak merupakan asas dasar terciptanya rumah tangga yang sakinah, mawaddah wa rahmah. ${ }^{43}$

Al- mu'asyarah bil-ma'ruf adalah dasar hubungan suami istri dalam Islam. Realisasinya adalah dengan cara bergaul dan berinteraksi yang baik. Hal itu bisa diwujudkan dengan adanya pelaksanaan hak dan kewajiban yang seimbang, perkataan dan perbuatan yang baik, dan hati yang penuh kasih. Melalui prinsip al-mu'asyarah bil-ma'ruf tersebut, kehangatan dan cinta kasih dalam keluarga akan tercipta sehingga diharapkan sakinah akan terwujud dalam sebuah rumah tangga.

\section{Prinsip Mubadalah dalam Hukum Keluarga Islam}

Jika kembali kepada pembahasan sebelumnya tentang konsep peran (role concept) yang diprakarsai oleh F. Ivan Nye yang menyatakan bahwa terdapat dua aliran dalam sosiologi mengenai konsep peran dalam keluarga, yaitu normatif dan interaksionis. Peran normatif memberikan gambaran bahwa sebuah keluarga dan para anggotanya mempunyai peran yang telah ditentukan dan bersifat rigid/tetap. Sedangkan peran interaksionis merupakan suatu konsepsi peran sebagai keteraturan tingkah laku yang dihasilkan dari wujud interaksi sosial, dengan kata lain bahwa peran itu muncul akibat dari adanya interaksi sosial. Menurut hemat penulis tidak demikian dalam Islam. Dalam kacamata Islam bahwa dalil-dalil keagamaan bukanlah suatu teks rigid yang tidak bisa ditafsirkan ulang. Kitab Suci mengandung kemungkinan makna yang tak terbatas, sehingga ia selalu terbuka dan tidak tertutup hanya pada satu penafsiran makna. Dengan demikian, melalui langkah ini ajaran Islam menjadi lebih fleksibel serta akan bisa dan mudah untuk diterapkan kapanpun, di manapun, dan oleh siapapun.

Dalam fiqh klasik dijelaskan bahwa hak dan kewajiban suami istri bertumpu pada tiga hal yaitu relasi yang baik, nafkah harta, dan layanan akan kebutuhan biologis (seks). Relasi tersebut harus bisa menguatkan dan mendatangkan kebaikan di antara pasangan suami-istri. Suatu relasi yang tidak dominatif baik dalam hal status sosial, sumber daya yang dibawa, serta jenis kelamin. Akan tetapi, itu adalah relasi berpasangan (zawaj), kesalingan (mubadalah), kemitraan (mu'awanah), dan kerja sama (musyarakah). ${ }^{44}$

Dengan demikian dalam hal nafkah maupun kebutuhan biologis merupakan hak dan sekaligus kewajiban bersama antara suami istri. Sehingga dengan menerapkan prinsip mubadalah dalam relasi suami istri diharapkan

${ }^{43}$ Sinta Nuriyah Abdurrahman Wahid, Wajah Baru Relasi Suami Istri Telaah Kitab 'Uqud al- Lujjayn (Yogyakarta: LKiS, 2001), 15.

${ }^{44}$ Faqihuddin Abdul Kodir, Qira'ah Mubadalah; Tafsir Progesif Untuk Keadilan Gender Dalam Islam (Yogyakarta: IRCiSoD, 2019), 370.

Kodifikasia: Jurnal Penelitian Islam, Volume, 14 No. 2 Tahun 2020 
lima pilar penyangga kehidupan berumah tangga bisa direalisasikan ${ }^{45}$, sekaligus meminimalisir praktek relasi gender yang timpang dalam keluarga.

Hal ini juga senada dengan relasi Aku-Engkau (I-Thou) ${ }^{46}$ yang diintrodusir oleh Martin Buber yang menyatakan bahwa bentuk dari relasi tersebut adalah suatu hubungan yang sangat mengutamakan dan mengedepankan adanya sikap 'saling' dari kedua belah pihak, ada dialog antara keduanya dan bukan hanya monolog. Inti pesan dari hubungan tersebut adalah memiliki makna yang global dan universal, yang ingin disampaikan kepada segenap insan di dunia tanpa membedakan dari mana mereka berasal baik dari segi golongan, bangsa, warna kulit, dan jenis kelamin, karena relasi Aku-Engkau menyeru kepada persamaan (equality).

Begitu juga dalam kehidupan rumah tangga, suami istri adalah subjek (Aku-Engkau/ I-Thou), dengan begitu keduanya mempunyai posisi serta peran yang setara dan seimbang. Hal demikian juga menunjukkan keberadaan hubungan dalam bentuk resiprokal (mutual relationship) antara kedua belah pihak (suami-istri), sehingga kecapakan sekaligus kemampuan keduanya pun tentunya juga sama. Bukan sebaliknya, bahwa seorang suami berperan sebagai subjek sedangkan istri berperan sebagai objek (AkuItu/I-It). Karena relasi tersebut membentuk dan menunjukkan sebuah pemisahan (the word of separation) ${ }^{47}$ dan perbedaan antara satu dengan yang lainnya. Hal tersebut merupakan bentuk hubungan yang tidak proporsional (imbalance relationship), sehingga akan menjadi berat sebelah karena seorang istri diposisikan sebagai sebuah "benda" yang bisa diperlakukan sesuka hati oleh sang pemilik, dalam konteks ini adalah suami. ${ }^{48}$

\section{PENUTUP}

Berinteraksi dengan cara yang baik (mu'asyarah bil al-ma'ruf) merupakan prinsip relasi suami istri dalam Islam. Praktiknya yaitu dengan mengimplementasikan hubungan resiprokal antara pasangan suami istri. Suami istri diharuskan bisa saling memahami dan melengkapi satu sama lain. Adapun hal lain yang perlu ditekankan di sini adalah bahwa dalam

${ }^{45}$ Lima pilar penyangga kebaikan dalam rumah tangga diantarannya adalah pertama, komitmen pada ikatan janji yang kokoh sebagai amanah Allah SWT (mitsaqan ghalidzan); Kedua, prinsip berpasangan dan berkesalingan (zawaj); Ketiga, perilaku saling memberi kenyamanan/kerelaan (taradhin); Keempat, saling memperlakukan dengan baik (mu'asyarah bil ma'ruf); Kelima, kebiasaan saling berunding bersama (musyawarah). Lihat detail Kodir, 343.

${ }^{46}$ https://id.wikipedia.org/wiki/Martin_Buber, diakses tanggal 30 Juli 2020.

${ }^{47}$ Baca selengkapnya tentang konsep relasi dari seorang Martin Buber di Martin Buber, I and Thou (Edinburgh: T. \& T. Clark, 1937), 23.

48 Anis Hidayatul Imtihanah, "Relasi Gender Keluarga Jama'ah Tabligh," Journal for Integrative Islamic Studies 3, no. 1 (2017): 33-68. 
kehidupan rumah tangga, suami istri juga harus mengoptimalkan peran dan fungsi masing- masing. Dengan demikian hubungan suami istri diletakkan atas dasar kemitrasejajaran dan kebersamaan tanpa harus ada paksaan maupun tindakan kekerasan di antara keduanya.

Prinsip mu'asyarah bil al- ma'ruf tersebut tidak hanya berlaku bagi pasangan suami- istri saja, akan tetapi juga berlaku bagi anggota keluarga yang lain. Sistem hubungan dengan prinsip simbiosis mutualisme seperti ini adalah sebagai salah satu cara dalam pembentukan rumah tangga yang sakinah, karena tidak akan ada praktik superioritas dan inferioritas dalam keluarga. Selain itu, keberadaan konsep mubadalah dalam Hukum Keluarga Islam adalah merupakan sebuah keniscayaan untuk mewujudkan tatanan hukum yang ramah gender dalam keluarga Islam. Dengan demikian hukum keluarga Islam yang ramah gender akan terealisasikan dan diaplikasikan dalam kehidupan rumah tangga, sehingga tidak hanya sekedar menjadi wacana saja. 


\section{DAFTAR RUJUKAN}

Agama RI, Departemen. Mushaf Al-Qur'an Terjemah, t,t.

Al-Umar, Nashir Sulaiman. Ada Surga Di Rumahku. Sukoharjo: Insan Kamil, 2007.

Ar Rusyidhi, Nur Chozin. Rahasia Keluarga Sakinah. Yogyakarta: Sabda Media, 2008.

As-Samaluthi, Nabil Muhammad Taufik. Pengaruh Agama Terhadap Struktur Keluarga. Surabaya: PT Bina Ilmu, 1987.

Ath- Thahir, Fathi Muhammad. Beginilah Seharusnya Suami Istri Saling Mencintai. Bandung: Irsyad Baitus Salam, 2006.

Aziz, Erwati. Relasi Jender Dalam Islam. Kartasura: PSW STAIN Surakarta Press, 2002.

Barlas, Asma. Cara Qur'an Membebaskan Perempuan/Believing Woman in Islam. Jakarta: PT. Serambi Ilmu Pustaka, 2003.

Buber, Martin. I and Thou. Edinburgh: T. \& T. Clark, 1937.

Chuzaifah Dkk, Yuniyanti. Realita Dan Cita Kesetaraan Gender Di UIN Jakarta: Baseline Dan Analisa Institusional Pengarusutamaan Gender Pada UIN Syarif Hidayatullah Jakarta Tahun 1999- 2003. Jakarta: Mc Gill IAIN- Indonesia Social Equity Project, 2004.

Connolly, Peter. Approaches to the Study of Religion. Yogyakarta: IRCiSoD, 2016.

Dachlan, Aisyah. Membina Rumah Tangga Bahagia Dan Peranan Agama Dalam Rumah Tangga. Jakarta: Jamunu, 1969.

Departemen Pendidikan Nasional. Kamus Besar Bahasa Indonesia. Jakarta: Balai Pustaka, 2001.

Doi, Abdur Rahman I. Women in Shariah (Islamic Law). Malaysia: A. S. Noordeen, 1992.

Huda, Miftahul. Filsafat Hukum Islam. Ponorogo: STAIN PO Press, 2006.

Imtihanah, Anis Hidayatul. "Relasi Gender Keluarga Jama'ah Tabligh." Journal for Integrative Islamic Studies 3, no. 1 (2017).

Istiadah, Istiadah. Pembagian Kerja Rumah Tangga Dalam Islam. Jakarta: Lembaga Kajian Agama dan Jender, 1999. 
Kodir, Faqihuddin Abdul. Qira'ah Mubadalah; Tafsir Progesif Untuk Keadilan Gender Dalam Islam. Yogyakarta: IRCiSoD, 2019.

Marhumah. Membina Keluarga Mawaddah Wa Rahmah Dalam Bingkai Sunnah Nabi. Yogyakarta: PSW IAIN Sunan Kalijaga, 2003.

Mayer, Ann Elizabeth. Islam Tradition and Politics Human Rights. Colorado: Westview Press, 1995.

Mazhahiri, Ayatullah Husain. Membangun Surga Dalam Rumah Tangga. Bogor: Yayasan IPABI, 1993.

Muhammad, Husein. Figh Perempuan: Refleksi Kiai Atas Wacana Agama Dan Gender. Yogyakarta: LKiS, 2001.

Mulyana. "Kualitas Keluarga", Dalam Imam Bahroni (Ed.), Dimensi Sosial Islam. Ponorogo: Perpustakaan ISID Kampus Al- Azhar, 2006.

Mulyati, Sri. Relasi Suami Istri Dalam Islam. Jakarta: PSW UIN Syarif Hidayatullah, 2004.

Munti, Ratna Batara. Perempuan Sebagai Kepala Rumah Tangga. Jakarta: Lembaga Kajian Agama dan Jender, 1999.

Najwah, Nurun. Relasi Ideal Suami Istri. Yogyakarta: PSW IAIN Sunan Kalijaga, 2002.

Nasution, Khoiruddin. Islam Tentang Relasi Suami Dan Istri; Hukum Perkawinan. Yogyakarta: ACAdeMIA+TAZZAFA, 2004.

Nye, F. Ivan. Role Structure and Analysis of the Family. USA: Sage Publication, 1976.

Ridha, Akram. Menghadirkan Kembali Kehangatan Dalam Rumah Tangga Kita. Surakarta: Ziyad Visi Media, 2007.

Setyawan, Cahya Edi. "Pemikiran Kesetaraan Gender Dan Feminisme Amina Wadud Tentang Eksistensi Wanita Dalam Kajian Hukum Keluarga." Zawiyah: Jurnal Pemikiran Islam 3, no. 1 (2017): 70-91.

Soekanto, Soerjono. Sosiologi Keluarga. Jakarta: PT RINEKA CIPTA, 2004. Soorma, C.A., and Al- Hajj Khwaja Kamaluddin. The Status of Woman in World Religions and Civilizations and Status of Woman in Islam. Bombay: Dar-ul-Isha'at-Kutub-e-Islami, 1996.

Susilaningsih. Dar-Ul-Isha'at-Kutub-e-Islami. Kerjasama UIN SUKA Yogyakarta dengan McGill-IAIN-Indonesia Social Equity Project, 2004. 
Syarif, Ahmad Arif. "Relasi Gender Suami Istri: Studi Pandangan Tokoh Aisyiyah.” Sawwa: Jurnal Studi Gender 13, no. 1 (2018): 85-106.

Wahid, Sinta Nuriyah Abdurrahman. Wajah Baru Relasi Suami Istri Telaah Kitab 'Uqud al- Lujjayn. Yogyakarta: LKiS, 2001. 
